\title{
CHANGING BUSINESS ENVIRONMENT
}

\section{Süleyman AÇIKALIN*}

\begin{abstract}
The globalization of the world economy is changing the environment of business world. Business sector should response to the latest changes by choosing appropriate policies. New Information Revolution era is redefining the structure of business operations all around the world. Global changes in technology require more and more skilled people. The old lines of doing business are declining from today's business agenda very rapidly. In this paper, the reader can find the latest changes and expected changes of next decade in international business. Environmental issues, cultural differences and political risks are main areas affecting the environment of international business world.

Keywords: Business enviromant, business policy, international business, information revaluation

Özet

Küresel ekonomik yapı iş dünyasının çevresel koşullarını dönüştürmektedir. Işletmeler hızla değişen çevresel ortama uygun yönetsel politikalar uygulayarak tepki vermektedir. Enformasyon devrimin yaşandığı yeni çağ, küresel anlamda işletme faaliyetlerini yeniden tanımlamaktadır. Dolayısyla küresel teknolojik değişim süreci daha nitelikli ve daha etkin işgücüne olan ihtiyacı artırmaktadır. Geleneksel çalışma yönetemleri ve kuralları günümüz işletmecilik anlayışının gündeminden hızla düşmektedir. $\mathrm{Bu}$ çalışmada, uluslararası işletme uygulamaları açısından son gelişmeler irdelenmektedir. Bu bağlamda kültürel farklılıklar ve siyasal riskler uluslararası işletmeler dünyasını etkileyen temel faktörler olarak değerlendirilmektedir.
\end{abstract}

Anahtar Kelimeler: İş çevresi, işletme politikası, uluslararası işletmecilik , bilgi devrimi

\section{Introduction}

* Öğr. Gör., Başkent Üniversitesi İktisadi ve İdari Bilimler Fakültesi 
The globalization of business results in big changes in the business environment and business operations. We can see four big transformations in the international business environment. All of them are happening simultaneously. They are causing one another and affecting one another. These transformations are so important in today's business and society that, business is in the revolution comparable in scale and consequence to the Industrial Revolution. These transformations are: the globalization of market economy, fast and constant change, a cutthroat competition, and the spread of information technology and computer networks. We can present four conditions necessary to succeed in such a world. "Employees must learn the new rules of work, companies and employees must be co-learners, companies have to make management a profession, and managers have to be worker-friendly." (Paez, December 17, 1996, p.13).

\section{Recent Developments}

Starting with late 1990s, no developed country had more than onesixth of its workforce in the roles of making goods and moving goods. In the US, already, two-thirds of employees work in the service sector. Knowledge becomes the most important product. This means new types of organizations as well as different kinds of workers. In 1985, there were 406,000 people working for IBM. In 1994, a third of the people were gone. Volkswagen says that, it needs just two-thirds of the people working now. Procter \& Gamble laid-off 12 percent of its employees despite to its rising sales in 1999. In today's business world, 9 to 5 workdays, lifetime jobs, hierarchical relationships, corporate culture security blankets are already gone or going. The workforce is replaced by a cybernetics workspace for a large and growing sector of the workforce. Today, constant training, retraining, job-hopping and even career-hoping become the norm. "It is not as if there is less work to be done; it is rather that some work is going to be done by people who do not have an employee relationship with the company. Significant amount of work is contracted out." (Paez, December 17, 1996, p.13).

In the late 1950s, integrated circuit is invented. Following this invention, more and more amount of information could be processed or stored in a single microchip. This can be called "Information Revolution". In 1960, the number of components on a chip was 1 and in 
1970 it became 1,000.This number reached 1 billion in 1992. Today's average consumers using PCs, have more power on their desks than it ever existed in the entire world before 1960. Computer power is 8,000 times cheaper relative to 1960s. Between 1983 and 1996, the US work world has added 25 million computers. By the end of 1993, the number of cellular phone users reached to 16 million. The speed and the amount of information flow are radically changed by the development of communication technology. This technological development requires for alterations in work roles all across organizations and decreasing the number of staff.

Companies' survival rate is getting lower and lower with the globalization of business. When we compare today's largest 100 companies and those in the beginning of 1900s in the US, we can see that only 16 of those from the beginning of this century are still in existence. In addition to this, the size and the reputation of companies did not guarantee continued success. We started to see very often mergers and new partnerships. Big companies realized that, a company can not do everything by itself. It needs to have a niche where to excel, and a comparative advantage. Mergers bring more saving by eliminating common support services and field operations, and by centralizing purchasing.

\section{New Rules for Success}

Now let's look at the new rules of success more carefully. The first condition for success in fast changing business environment is that employees must learn new rules of work. According to old rules, employees knew that, if they did a decent job and kept themselves out of problems, they would have employment for life. They assumed that their company would be around forever. By the new rules, every employee must be a contributor and they must contribute more than what they cost to company. In today's work world it is not good for employee or for the company, for employee to stay in the same company for his/her entire career. With the new rule, old lifetime jobs are decreasing in company culture. An employee should know that, only by adding costs to company but not adding value, he/she can not stay in that company for long. Most of the times, employees mislead themselves by thinking that they should keep their job if they are responsible and do good job. Even they can 
think that if they stay in the same company for longtime, they can be more valuable. In the old work world, the number of hours they put to their job and to company was the basis for their value to their company.

However, today only their contribution counts. There are people working very hard without adding any value to company. They think that just their effort earns them a paycheck. The company can appreciate their work effort, but this does not mean that the company should keep them. Today, employees should think that, their performance and the value they added to the company means paycheck. Employees must make a difference for the company to prove that they are valuable to the organization. They need do add enough value so that when they left, everyone should understand their worth.

Forecasting changes in the business world is crucial for the preparation of response to them. Now we should look at the possible changes in the global business environment over the next decade and the impacts on business operations. In the last decade, executives took globalization to their strategic agendas; government officials have increased their debate of and involvement in international trade and investment issues; and universities increased their research to address international business issues. We can look at the possible changes under the following groups: geographic issues, sectoral transformations, institutional and framework issues, and corporate adjustment strategies.

The emerging markets of the Asia-Pacific and Latin America will be the motorpower of global economic growth. Once we witnessed to the last financial crisis in Asia we know that the speed of this growth can be threatened by uncertainties in these areas. However, the future growth will be important and any slowdown in the growth will be mainly the result of getting mature of these emerging markets. Uncertainties in these areas are political and social tensions of these countries arising from unequal income distribution. Inadequacies in infrastructure, both physical such as transportation and abstract such as legal systems are another area for concerns about uncertainties. The Asia-Pacific seems to be the hottest spot of interest. "The area is predicted to grow into a massive economic, political and technological production power, with simultaneously increasing regional consumer demand. For the industrialized countries, this presents significant export and investment opportunities, but also 
diminishes, in the longer term, the basis of their status and influence in the world economy." (Czinkota, and Ronkainen, December 22, 1997, p.833).

We can look at the big growth of China as the economic event of the decade. Despite the innumerable risks and significant expectations for change, still China offers opportunities for outside participation. Some investors think that, the lack of predictability of Chinese demand and missing legal infrastructure are obstacles for foreign investment. However, these problems can be worked out through market mechanism and eventual rapid development of corporate law. To be successful in China, international companies should commit to long-term relations, be willing to transfer new technologies, and have the ability to partner with local firms through joint ventures or close relationships with overseas Chinese firms. Other important markets are Korea and India. Korea up to last financial crisis developed very fast to become competitive worldwide. The size of its population and so the size of its potential market is making India important. India is a big country and has significant natural resources and highly educated middle class.

With the considerable economic liberalization in India during the 1990s, major international marketing opportunities will emerge. Japan will stay as a hot spot, leading the Asia-Pacific region. The international business interest for Latin America will improve due to economic integration, market liberalization and privatization. In the next decade, not only the US but also Japan and Europe will increase their foreign direct investment to Latin America, since the region has substantial natural resources, and relatively low cost of production. North America will be a warm spot. The economic growth of the region will be moderate level, but, the over-proportional consumptive power of the region will continue to make North America a targeted export destination. Europe and the Less Developed Countries in Africa will be least favorable regions for international business opportunities. The ongoing economic liberalization and inclusion of new members are positive developments for Western Europe. However, divergent nationalist pressures and conflicts on the currency are seen as the counterweights to do business. Low labor cost, low-cost input factors and large unused production capacities are the reasons to attract international business operations to the Central and Eastern Europe. Russia and other members of old Soviet 
Union are facing the largest difficulties in the Europe. Their economic recovery is very slow, because of self-imposed constraints resulting from domestic fears of outsiders. The political instability and the resulting inability of many African countries and firms to be consistent trading partners are the key reasons to why developing countries of Africa are not good contestants for international business operations.

When we look at the transformations in the sectoral structure we can see that the largest expectations are for service sector. Competition in this sector will increase sharply because of market openings accompanied by greater ease of reach by service providers. Information revolution is the main cause of this transformation. The declining cost of using information infrastructure will offer service providers new ways of communication with customers. Service providers will develop new marketing techniques. The most important of these new techniques will be the rise of micro-marketing efforts specifically designed for individual demands. The speed of decisionmaking will increase with the help of enhanced information transparency. As a result, we can see service transactions as the closest to the pure market force model in the next decade. A new industry of structuring knowledge is likely to emerge because of the growing risk of information overload. Knowledge distribution experts will specialize in two areas. "Knowledge Focusers will be in charge of meshing data sets and ensuring that the right kind of information is provided as parsimoniously as possible. Knowledge Erasers will concentrate on weeding out old or unnecessary data, in order to limit capacity constraints of information banks and to delete corporate information that may lead to future interpretation problems." (Czinkota, and Ronkainen, December 22, 1997, p.836).

Financial and telecommunication sectors will be the most affected service industries by transformations. The integration leading to bank acquisitions and the reduction in financial intermediaries will continue. Customers will have direct connection to financial markets and the ability to present their demands in global perspective. Commercial banks will have to use more of electronic money and credit activities managed by independent brokers and risk management firms. On the international level, borrowers will have easy and direct access to the global capital market; and this will rise the competition for domestic financial institutions. The poor management of short-term of investment capital in 
developing world will call for a re-establishment for risk-assessment teams. The collection, evaluation and rating of country information will be responsibility of these teams rather than banks. Markets and their financial needs will expand and therefore there will be a great rise for financing needs. There will be greater mobility of capital. The growth of countertrade, self-financing programs of corporate groups and other innovative alternative financing packages will be result of an increase in the privatization of government financing accompanied by a growing need for new financial products and providers. The fast development in international telecommunications will need more corporate technology investment and ever faster response times. These technological developments in telecommunication will create significant independent communities, it will be very important for firms to be part of such networks. Transformation in telecommunication will also make important changes in business and employment transactions. On the employment side, a detachment from any location will become increasingly possible, thus raising productivity. On the transactions side, electronic forms of commerce will expand and leading to harsher competition and more consumer choice.

Manufacturing will also be affected by industrial transformations. The speed in the technological innovations will create new products. Faster knowledge transfer through new technologies will create possibilities for more concentration of product expertise, increased division of labor and a proliferation of global operations. The speed of production and production delivery will gain acceleration through information shifts. Biotechnology, aerospace and automotive industries will be leading fields for the fastest changes in the manufacturing sector. Genetic engineering will have a major effect on the growth and supply of agricultural products. Major advances can also be expected for pharmaceutical fields. This development will be driven by the growing competition between the US, Japanese and Western European firms. However there is a potential danger for this field. That is, countries can compete against each other on the basis of regulatory laxness, in order to attract biotechnology industries and speed products to market. In the automotive sector, competition will be on the basis of clean car issues as environmental demands escalate. Investment into manufacturing facilities 
in numerous parts of the world rather than trade will be the main stream of this industry's globalization.

The role of intellectual property will be the most important one in institutional and framework issues. We know that the importance of technology will continue with a rising trend; therefore creative concepts, and the process as a basis for competitive advantage, the protection of patents, copyrights and trademarks will be the most important assets to be safeguarded. The lack of adequate legislation and its enforcement will be key problems with the speeding technology. Multilateral agreements, especially through the WTO, and bilateral pressure will be the most possible public alternatives to the private solution to above mentioned problems. However, many economists believe that, the true protection is the autocontrol of companies. Then the best policy by public authorities can be providing a domestic environment that is conducive to such progress by companies themselves. Environmental issues will not receive same level of attention and urgency as in the last decade. According to experts, concerns toward environment showed by governments and consumers will create self-responsible manufacturers. Global companies having the ability to transfer innovations and programs between markets easily and quickly can be long-term winners, when public concern for deterioration of environment creates new product opportunities.

The dislocations caused by currency swings accompanied by speculative portfolio investment flows will support governments to aim for increased currency stabilization. As more firms become international, business world also will ask for such stabilization. Therefore, an organization supported by the US, Europe and Japan will become active by participating in, if not managing, global financial markets and severely affecting national monetary policies. Eventhough, the timing of full monetary integration within the EU was questionable; everybody believes that it will be done. As a result, the emergence of new currency in the European Union will affect the important position of US dollar for international financial transactions and reserve purposes. The World Trade Organization strengthens the international framework of trade. The growth of enforcement capability of the WTO will provide more consistency and trade relations despite the growing forces of regionalism. Large players will continue to affect trade and investment activities on a 
global scale. Because, their interpretation and application of established rules will be able to change the activities of lesser trading partners.

"Increasingly, there will also be an assumption of heretofore sovereign policy formulation by individuals, special interest groups and corporations. For example, in the area of moral behavior, firms will be subject not just to government rules, but will also be held accountable by the public at large." (Czinkota, and Ronkainen, December 22, 1997, p.840). Human rights will be a growing concern for the employment organizations in firms. If a firm takes an action considered wrong by concerned individuals, these actions will be told to many interest groups and customers. Firms will face to public scorn, consumer boycotts and investor scrutiny that may be more important than the government fees. Therefore firms will realize that consumer expectations become a new benchmark for corporate operations. An era of global communication means an era of global scrutiny for firms. Companies will have to invest more into community relations than before.

The next decade's firms will need a simultaneous presence in the Americas, Europe, and the Asia-Pacific to respond to enduring regional preferences and gain and ensure their competitive positions. There will be re-engineering of companies based on core business strengths and the pursuit of niche strategies on a global basis. Economic liberalization will increase offshore investments. Competitive pressure will lead to increased overseas sourcing. The number of markets around the world entered by corporations will go up. The ethnicity feelings are getting stronger among consumers in individual markets. These two events will call for more effective management of cultural and ethnic diversity within a corporation. The growth of the number of global organizational customers, including intermediaries will be another source to drive globalization. As a response to this companies will have to follow them and develop strategic responses to their needs. One example is global management programs. Global strategies will have a very important impact on the organization of firms. The leverage of corporate capabilities around the world in support of operations in each country will be the key element to be successful. By doing so, the company as a whole will be larger than the sum of its parts. Developing global strategy and securing effective implementation of such strategies at both domestic and international levels require a series of organizational initiatives. The 
determination of what should and what should not be centralized and standardized will be the critical challenges. The more tactical the function, the more it should stay in the domestic market; the more strategic the element, the more opportunity for international coordination. As a consequence of learning, the major control of strategic elements will allow for the leveraging of capabilities and company wide use of best practice. One of the most distinct organizational initiatives will focus on the building of networks. Part of the need for increased interaction on all levels is making employees' view global. Human resource management will require more flexibility and creativity to secure the type of employees needed to implement global strategies. The challenge will be finding of those who either already know or are able to learn and assimilate national differences into their thinking. If there are not enough skills, then increased investments in recruitment, training and development, as well as programs directed at retaining personnel are needed.

As a result of this section, we can summarize our expectations and findings about the next decade of international business. Firms may concentrate their expansion plans on Asia and Latin America. The major emphasis for this expansion will be on infrastructure. For the companies, another important development is the information network; they should develop and participate in this network accompanied with the development of global logistics systems. It will be of major importance to understand and follow the development of administrative rules. Companies should also develop a group within their organizations to deal with the special interest groups. In the US, trade policy formulation is becoming less and less in the form of unilateralism. Also companies should see that the enforcement capability of WTO is increasing. On a global level, more and more flexibility towards financial sectors should encourage companies into these sectors to adjust to rapid changes. Biotechnology, administrative trade rules and intellectual property rights will require more global harmonization for regulations. Export development processes and the role of global information structure and dissemination will be investigated further. These investigations can give useful information about the network formation and the management of logistics systems. In the global financial sector, new approaches should 
be developed for the decline of currency fluctuations and the new role of countertrade.

\section{The Impact of Environmental Issues}

Now, let's look at the importance and the impact of environmental issues on business world, more carefully. Business world should understand the importance of environmental issues and will develop strategies for ecological management. Preventing pollution at the source rather than cleaning up later, and staying ahead of current environmental standards will be wise principles in ecological management. A safe environmental strategy should be based on doing what is ecologically correct, rather than based on how long we can abuse some currently unregulated form of environmental issues. "Wise executives will: 1. Avoid doing business with suppliers that take ecological shortcuts, 2. Hasten the end of bureaucracy, 3. Make every individual in the organization assume responsibility for environmental protection, 4. Take preventive and corrective environmental action, 5. Measure for environmental impact, and 6. Promote self-organizing systems." (Gifford, October 1992, p.7). Global warming and the hole in the ozone layer are very serious issues even today. The rate of species extinction is rising very rapidly; and there is no end to this in sight. Therefore the pressure for environmental responsibility is growing day by day.

When we look at the American automobile industry, we see initially wrong approach to environmental issues. When the US government took mandatory regulations about emission and fuel economy standards, automobile makers devoted too much energy to fighting the standards and not enough to meeting them. For years, American cars coughed to meet the standards while Japanese cars proved themselves through pollution tests. This factor and as well as others, consumers in the US started to feel that the quality of American cars are low, relative to Japanese cars. The US automakers' share dropped dramatically, because of their failure to meet the mandatory environmental design.

Wise business men should take major steps to adjust their organizations with sustainable systems now. If non-sustainable systems were taken, then when environmental turmoil shakes some larger system of in which the business is working, it will bring unacceptable risk of business failure. Most probably, customers and banks may not want to 
work with that company, if that company decided to take that risk. Banks started to demand environmental assessments before making loans. Serious environmental problems can easily affect negatively the balance sheet and the income statement of a company.

We should investigate the six principles a bit further. First one was "avoid doing business with suppliers who take ecological shortcuts". Companies should not work such suppliers for two reasons. First is to keep their people inspired. Second is the fear of getting their environmental rating downgraded. Companies should be aware that new investment money will flow toward ecologically safe projects. Therefore they should strive on a personal and a corporate level to become ecologically wise. The second principle was "hasten the end of bureaucracy". The ecological trend will create many complex dilemmas. Executives will deal with so many complex dilemmas that bureaucracy can not handle. In the industrial era, main scientific model was physics and linear cause and effect. Bureaucratic people dealt with these models. Now, the most fundamental law is "everything connects to everything else". Bureaucratic people can not deal with today's problems any longer. The new systems that will replace bureaucracy will effectively deal with many complex dilemmas, none of which permit simple or universal solutions. This level of complexity requires the intelligence of every member, great freedom and strong discipline to work together for the longer-term. Third principle was "make every individual an ecological champion". Environmental responsibility can not be limited to executives or staff group any more; everyone in companies must feel to serve both to customers and to the environment. Nowadays, good executives are making wise statements of ecological concern. "For example, Stephen M. Wolfe, chairman of United Airlines, writes, "Whether one is a conservationist or not, it can not be denied that the specter hovering over endangered wildlife casts a shadow on the earth-and ultimately threatens the existence of all species, including mankind." Wolfe is lighting an environmental fire in the hearts of employees and giving bigpicture thinking legitimacy." (Gifford, October 1992, p.12). "Take preventive and corrective environmental action" is the next principle. The real defenders of the environment within and without the company will look roles beyond the mandatory regulations. They will serve as educators, coaches, teammates and leaders. One of the most important 
jobs of them will be making it easier for others to prevent pollution. The fifth principle was "measure for environmental impact". Companies should get better measurement of ecologically significant variables, since they know that, they get what they measure for. The last principle was promoting self-organizing systems. Companies should organize in a highly interconnected self-organizing system instead of organizing in a group of lightly connected feudal fiefdoms. Companies having selforganizing systems and employees with the freedom and the intention to seek solutions will flourish in the environmental era. These systems need freedom, but the organizations should be in full of ethical and biologically wise members. With the new environmental problems, companies will have to develop local and global systems that anticipate environmental problems and empower people to act to prevent them. They will create intelligent, wise and better organizations instead of bureaucracy. The challenge will be educational, structural, moral, visionary, and practical.

\section{Cultural Complexity}

Cultural differences are another concern of today's big companies and will continue to be concern with the continuous globalization of business world. According to Holfstede, culture is defined as the collective programming of the mind that distinguishes the members of one human group from another. Religion, location, family origins and solidarity, politics, economics, and social and philosophical history are some of the programming influences. Some writers of international business say that, people of a country see their behavior as based on the norm and others as abnormal. In addition to this, people do not want to see how their own culture affects their behavior. People mostly suffer from cultural blindness. After we define culture, we can look at the cultural differences between East and West and how this affects the business relations. Eastern cultural values are generally derived from a communal society. On the other hand, the Western values have a basis on individualistic society. Community interests, dependence, and social harmony are the examples to Eastern values. Whereas, self-interest, free choice, and independence are the values of Western culture. However, they are by no means to be seen as generalizations. Generalization can give problems as many as knowing nothing at all about cultural differences. People should also know that cultures change. When you 
think that you learned another culture, you can see that you get it wrong. This means that people should give attention to body language and behavior that indicate whether they are winning or losing.

The learning of business culture is a group under secondary socialization which is the learning of additional cultures relevant to a person's participation in the wider socioeconomic world. Business cultures comprise the rules of the game, the limits between competitive and unethical behavior, and the codes for conduct in business dealings. As an example we can look at the priorities of French and American financial managers. French ones are more concerned with the solvency, while American ones are more concerned with return on investment. In companies with international operations, the international marketing department gathers foreign marketing intelligence. "Multinational firms are far more proficient at managing the more technical and quantifiable tasks such as accounting, finance, manufacturing, and logistics, than they are at managing more culturally sensitive tasks such as personnel management and marketing. All business functions, but especially these latter areas, can be aided by intercultural management." (David, and Terpstra, 1985, p.13). Firms with extensive intercultural business relationships face the decision on appropriate cultural policy just as they face the problem of appropriate technology and appropriate product policy. A firm's corporate culture is limited by its country's societal and task environments. In many situations, firms can not impose their corporate culture on their foreign partners. The answer to these situations can differ from case to case. The crucial point is that cultural policy can not be stated monolithically to apply to all business situations.

The inability to interact effectively in a cross-cultural interchange can lead to misunderstanding and have a negative impact on people and business between two countries. "For effective intercultural exchange, one should: 1. Communicate respect, 2. Be non-judgmental, 3. Realize that perceptions are personal, 4. Show empathy, and 5. Tolerate ambiguity." (Mu, March 15, 1995, p.6). Honesty, trust, courage, respect for human dignity, fairness and love are the shared values necessary for the existence of human social groups. These values may not be observed directly. Behavior is what we observe and the interpretation of it is the expression of certain values. Therefore, we know that all cultures share these values, but behaviors can be different and subject to interpretation. 
Having those six skills mentioned above, will help improve intercultural exchange required for today's business world. The ability to express respect for others is an important part of conducting effective relations in every country. When interacting with people from another culture, one should know how to show respect for them. Avoiding moralistic and evaluative statements is another important aspect. Most people like to feel that first, they will have opportunity to fully explain themselves and then what they say or do can be judged. People should recognize the impact of one's own values, perceptions, opinions and knowledge on human interactions and regard them as relative. Ability to put yourself in someone else's shoes is another required skill. In order to cope with cultural differences within the company or in the international business area, the ability to react new, different and unpredictable situations is one of the most important aspects. People should accept a degree of frustration, deal with changed circumstances and people with little visible discomfort or irritation. Learning to manage the feelings associated with ambiguity is a skill necessary for those who must adapt to anew environment and work effectively with people from different cultural backgrounds.

\section{The Role of Political Risk}

As a last part to this paper, I would like to look at the concept of political risk and its effect on international business. Political risk can be defined as uncertainty of the political environment of business and its effects on firms. The definition and explanation of political risk is important to predict such conditions more accurately. Once firms defined and had their predictions, they can develop their response to such conditions. In financial theory, risk refers to the variability in returns. The greater the variability in returns, the greater the risk. Generally, governments offer insurance programs to cover political risks of doing business. Bankers generally focus on the possibility of non-repayments of loans. They refer to this kind of risk as country risk. Economics and politics are closely related with each other. "(1) economic behavior is often induced by political relationships, and economic resources are often used as sanctions or rewards in political relationships; (2) economic values are frequently central to (political) struggles over the allocation of scarce values; and (3) economic goals are often sought through collective (political) decision-making processes." (Brewer, 1985, p.8). The benefits 
of international portfolio diversification have been recognized for a long time. An internationally diversified portfolio is substantially less risky than a purely domestic portfolio, since return on stock have much lower positive correlation across countries than within a country. However, the political risk of foreign investment can decline the importance of international diversification. Most probably, the political risk especially in developing countries will affect the international portfolio investment decisions of big companies negatively. On the other hand, according to some economists, political risk assessments are overstated. Investors should not avoid the politically unstable markets of the world, because returns to these investments might overweight taken risk. "Political risk might even favor foreign investors relative to domestic investors to the extent that these risks are domestic phenomena that can be diversified internationally." (Cosset, and Suret, 1995, p.303).

\section{Conclusion}

Changes in the business environment and business operations are coming with the rapid globalization of business. Transformations in the international business environment are happening simultaneously. They are causing one another and affecting one another at the same time. These transformations are so important in today's business and society that, they are called as "Information Age" and compared with the "Industrial Revolution". Companies should develop and participate in information network accompanied with the development of global logistics systems. It will be of major importance to understand and follow the development of administrative rules. On a global level, more and more flexibility towards financial sectors should encourage companies into these sectors to adjust to rapid changes. Biotechnology, administrative trade rules and intellectual property rights will require more global harmonization for regulations. Future investigations on these areas can give useful information about the network formation and the management of logistics systems. Business world should understand the importance of environmental issues and will develop strategies for ecological management. Preventing pollution at the source rather than cleaning up later is more effective way in any sense. Staying ahead of current environmental standards will be clever idea for the companies wanting to lead their sectors. A safe environmental strategy should be based on doing what is ecologically correct, rather than based on how long we can 
abuse some currently unregulated form of environmental issues. Cultural differences will be main issue of future's multinational companies and even of the national companies. In order to cope with cultural differences within the company or in the international business area, the ability to react new, different and unpredictable situations will be required skills for employees. People should accept a degree of frustration, deal with changed circumstances and people with little visible discomfort or irritation. Learning to manage the feelings associated with ambiguity is a skill necessary for those who must adapt to a new environment and work effectively with people from different cultural backgrounds. Political risk of especially developing countries can produce positive as well as negative signs for the companies to expand overseas. The political risk of foreign investment will have a negative effect on the importance of international diversification. On the other hand, investors should be aware of that the politically unstable markets of the world may have higher returns enough to overweight the cost of political risks taken.

\section{References}

Brewer. T., L., Political Risks in International Business, Praeger Publishers, New York. 1985, pp.3-15.

Cosset, Jean-Claude, and Suret, Jean-Marc, Political Risk and the Benefits of International Portfolio Diversification. Journal of International Business Studies, Vol.26, No.2, 1995, pp.301-316.

Czinkota, Michael, R., and Ronkainen, Ilkka, A., International Business and Trade in the Next Decade: Report from a Delphi Study. Journal of International Business Studies, Vol.28, No.4, December 22, 1997, pp.827-845.

David, Kenneth, and Terpstra, Vern, The Cultural Environment of International Business, South-Western Publishing Co., Cincinnati, Ohio. 1985, pp.1-17.

Gifford, Pinchot, The Ecology of Success. Executive Excellence, Vol.9, No.10. October 1992, pp.7-12.

$\mathrm{Mu}$, Dan Ping, Culture and Business. East Asian Executive Reports, Vol.17, No.3, March 15, 1995, pp.6-17.

Paez, J., The Changing Roles of Managers. New Straits Times (Malaysia), Section: Management, December 17, 1996 p.13. 